\title{
Isaria javanica (anamorphic Cordycipitaceae) isolated from gypsy moth larvae, Lymantria dispar (Lepidoptera: Lymantriidae), in Japan
}

\author{
Mitsuaki SHIMAZU* and Jun TAKATSUKA \\ Forestry and Forest Products Research Institute; Tsukuba, Ibaraki 305-8687, Japan
}

(Received 29 January 2010; Accepted 31 May 2010)

\begin{abstract}
An entomopathogenic fungus, Isaria javanica (anamorphic Cordycipitaceae) was isolated from diseased larvae of the gypsy moth, Lymantria dispar, in outbreak populations from Iwate Prefecture, in northern Japan in the summer of 2008. The fungus caused a mixed infection with Entomophaga maimaiga in the gypsy moth populations. The fungus forms conidial chains on phialides verticillate on conidiophores, with conidia fusiform to oval, 3.0-4.3-6.3 $\times$ 1.4-2.0-3.2 $\mu \mathrm{m}$, chlamydospores and synnemata absent, and grows on SDAY medium at $10-30^{\circ} \mathrm{C}$, with optimal growth at $25^{\circ} \mathrm{C}$. Phylogenetic analyses, using the $\beta$-tubulin gene and internal transcribed spacer (ITS) rDNA, positioned the fungal isolates to a well supported branch where I. javanica was included. The dipping of larvae into the conidial suspension revealed a moderate virulence of the fungus to the gypsy moth (mortality 58-100\% with $10^{8} / \mathrm{ml}$ ). This is the first discovery of I. javanica on L. dispar larvae.
\end{abstract}

Key words: Lymantria dispar; Isaria javanica; Paecilomyces; fungi; outbreak

\section{INTRODUCTION}

In the summer of 2008, outbreaks of the gypsy moth, Lymantria dispar Motschulsky, occurred in Iwate Prefecture in northern Japan. The larvae largely defoliated Japanese larch, Larix leptolepis Murray. Most larvae were 6th instars at the investigation on July 16, 2008. Many dead larvae, as well as living larvae, were found on the surface of boles of the host trees. Investigation of the gypsy moth cadavers revealed that most larvae were infected with the nuclear polyhedrosis virus (NPV), the fungal pathogen Entomophaga maimaiga (Zygomycota: Entomophthorales), or a mixed infection of those two pathogens. These cadavers were softened, but there were also other types of cadavers infested with another fungus. After investigations of these specimens in the laboratory, the larvae were found to be infected with an anamorphic fungus, identified as Isaria javanica. Since there has been no report of this fungus from the gypsy moth, its morphological and cultural features, and pathogenicity against gypsy moth larvae, were investigated.

\section{MATERIALS AND METHODS}

Fungal isolates from Lymantria dispar. Live and dead larvae of the gypsy moth were collected from several sites in Iwate Prefecture to investigate naturally occurring pathogens in the outbreak populations. Among the collection sites, muscardine cadavers were found from only two sites in Ninohe City, Iwate (Fig. 1). Site A was a mixed plantation of Japanese larch, Larix leptolepis, and alder, Alnus japonica. The diameter breast heights (DBHs) of both species were around $20 \mathrm{~cm}$. Site B was a solitary chestnut tree, Castanea crenata $(\mathrm{DBH}=\mathrm{ca} 40 \mathrm{~cm})$, along a road. Specimens of the larvae with white muscardine fungi were collected from Site A on July 16, 2008, and Site B on October 22, 2008, and brought to the laboratory.

Fungi were isolated from the conidia formed on the surfaces of the cadavers. Conidia were isolated by streaking them onto plates of Sabouraud's Dextrose Agar with 1\% yeast extract (SDAY). The plates were incubated at $25^{\circ} \mathrm{C}$ for about $7 \mathrm{~d}$ and the obtained colonies were retrieved to isolate.

Morphology of isolates. Conidia and conidio-

* To whom correspondence should be addressed at: E-mail: shimazu@ffpri.affrc.go.jp DOI: 10.1303/aez.2010.497 


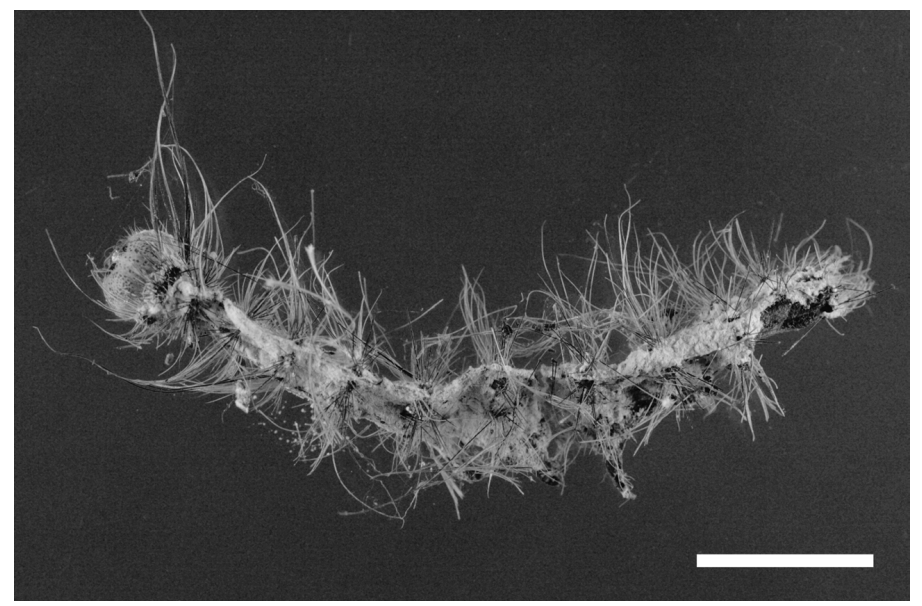

Fig. 1. A Lymantria dispar larva infected with Isaria javanica $(\mathrm{Bar}=10 \mathrm{~mm})$.

genous structures of the isolates were observed. Specimens were taken from both the larval cadavers collected in the Iwate fields and from the isolated culture on SDAY plates at $25^{\circ} \mathrm{C}$ for $21 \mathrm{~d}$ under continuous fluorescent light. Conidia and phialides were mounted in an aqueous solution of $0.85 \% \mathrm{NaCl}$ with $3.5 \%$ formaldehyde (PSF) onto glass slides. The lengths and widths of conidia were viewed on a TV monitor connected to a microscope, measured using a digital caliper and converted to actual sizes. Isolates were cultured on sterilized glass slides with SDAY and observed with a microscope to investigate conidiogenous structures.

Mycelial growth at various temperatures. Mycelial growths of an isolate, F-2754, were compared on two kinds of culture media at various temperatures. Plates of SDAY and Malt Extract Agar medium (MEA: malt extract 20 g, Bactopeptone $1 \mathrm{~g}$, dextrose $20 \mathrm{~g}$, and agar $15 \mathrm{~g}$ in $1,000 \mathrm{ml}$ of distilled water) were prepared in $86 \times 15 \mathrm{~mm}$ Petri dishes. As inoculum for the agar plates, the fungus was cultured in Sabouraud's Saccharose Broth with $1 \%$ yeast extract in a shaker incubator at $25^{\circ} \mathrm{C}$ for $5 \mathrm{~d}$ to produce a suspension of hyphal bodies. A drop of the suspension was inoculated at the center of each agar plate with a platinum loop and dried. The plates were then incubated at 10, 15, 20, 25, 30 and $32.5^{\circ} \mathrm{C}$ for $14 \mathrm{~d}$ in total darkness. For each temperature, four plates were replicated. Two perpendicularly intersecting diameters of each colony were measured and the mean was determined. Growth of the fungus at each temperature was obtained by subtracting the diameter on day 0 from that on day 14.

Molecular analysis. Isolates were cultured on SDAY for $5 \mathrm{~d}$ at $25^{\circ} \mathrm{C}$. Mycelia were scraped from the plates using a $200-\mu 1$ pipette tip and suspended in TE buffer. Each suspension was homogenized with a hand homogenizer for $30 \mathrm{~s}$, and DNA was extracted using a PUREGENE Tissue DNA Purification kit (Qiagen, Tokyo, Japan). Polymerase chain reactions (PCRs) were performed to amplify partial sequences of the $\beta$-tubulin gene with primers bt2a and bt2b (Glass and Donaldson, 1995) and the ITS rDNA with primers ITS4 and ITS5 (White et al., 1990). Amplification reactions were carried out in volumes of $50 \mu \mathrm{l}$ containing $200 \mu \mathrm{M}$ dNTPs, 0.5 units of rTaq DNA polymerase (Takara Bio Inc., Shiga, Japan), $0.4 \mu \mathrm{M}$ primer, $1 \times$ PCR buffer (Takara Bio Inc.), and $10 \mathrm{ng}$ of template DNA. PCR conditions for $\beta$-tubulin gene were 1 cycle at $95^{\circ} \mathrm{C}$ for $4 \mathrm{~min}$, followed by $35 \mathrm{cy}$ cles at $95^{\circ} \mathrm{C}$ for $1 \mathrm{~min}, 58^{\circ} \mathrm{C}$ for $1 \mathrm{~min}, 72^{\circ} \mathrm{C}$ for 2 min, and then 1 cycle at $72^{\circ} \mathrm{C}$ for $7 \mathrm{~min}$. ITS rDNA was amplified with the same PCR conditions, except for an annealing temperature of $55^{\circ} \mathrm{C}$. From each PCR-product solution, $3 \mu \mathrm{l}$ was electrophoresed through a $1.5 \%$ agarose gel, stained with ethidium bromide and visualized with ultraviolet light to check for the specific amplification of single bands. Singly amplified products of 350 and $550 \mathrm{bp}$ for the $\beta$-tubulin gene and ITS rDNA, respectively, were purified using QIAquick PCR Purification kit (Qiagen, Tokyo, Japan) and subcloned into the p3T cloning vector (MoBiTec GmbH, Göttingen, Germany). DNA-sequence analysis of both strands was performed with a cap- 
illary sequencer (ABI 3130XL; Applied Biosystems, Foster City, CA, USA). Three clones were sequenced for each strand. DNA sequences were subjected to a Basic Local Alignment Search Tool (BLAST) search to identify sequences deposited in GenBank that had a significant homology. The sequences were aligned with fungi belonging to the 'Isaria' clade (Luangsa-ard et al., 2005) and related fungi using ClustalW incorporated in MEGA 4 (Tamura et al., 2007). Alignment gaps were treated as missing data in the analyses. Phylogenetic trees were constructed by the neighbor-joining method of MEGA 4 (Tamura et al., 2007). Bootstrap analyses of 1,000 replications were performed to determine the supporting values of branches. Byssochlamys nivea and B. fulva were the designated outgroups.

Bioassay. Gypsy moth larvae were inoculated with isolate F-2754 to check for pathogenicity. The fungus was cultured on SDAY plates at $25^{\circ} \mathrm{C}$ for $26 \mathrm{~d}$. The obtained conidia were suspended in an aqueous solution of Tween 80 (300 ppm) and filtered through a tissue paper, JK-Wiper ${ }^{\circledR}$ (Kimberly-Clark Worldwide, Inc.), to remove hyphae and conidial masses. The suspension was diluted to make densities of five concentrations: $1 \times 10^{4}$ through $1 \times 10^{8} / \mathrm{ml}$. The $L$. dispar larvae used for the inoculation experiments were laboratory-reared 3rd and 4th instars from egg masses collected in Iwate Prefecture. Surfaces of the egg masses were sterilized by soaking them in $2 \%$ formaldehyde solution for $20 \mathrm{~min}$ after removing the hairs. Larvae were dipped into the F-2754 conidial suspension for 10 to $30 \mathrm{~s}$, placed on a paper towel to absorb excess suspension, and reared at $25^{\circ} \mathrm{C}$ on Rhododendron pulchrum leaves for $25 \mathrm{~d}$. Ten individuals were usually used for each concentration and instar. No replicate was prepared for 3 rd instars but two replicates were used for the 4th instars.

\section{RESULTS}

\section{Morphology of isolates from Lymantria dispar}

Three isolates from three muscardine cadavers of $L$. dispar were derived from Site A. These isolates were named F-2753, F-2754 and F-2755. Two other isolates were derived from Site B and named F-2811 and F-2812. All of these isolates had the same morphological features and were thought to be the same species. Mycelia on both host bodies and the SDAY medium were grayish white, and the fungus did not form distinct synnema. Conidiogenous structures were phialidic and conidia formed in a chain on verticillate phialides (Fig. 2). Chlamydospores absent. Phialides flask shaped, $5.1-7.6-10.9 \times 1.8-2.3-2.8 \mu \mathrm{m}$ on hosts, and 4.6-8.0-13.5 $\times 1.8-2.0-2.6 \mu \mathrm{m}$ on SDAY medium. Conidia white or grayish white in mass, fusiform to oval, both ends often pointed. Mean conidial dimensions of the five isolates were 3.1-4.3-6.3 $\times$ 1.4-2.0-3.1 $\mu \mathrm{m}$. Detailed dimensions are shown in Fig. 3.
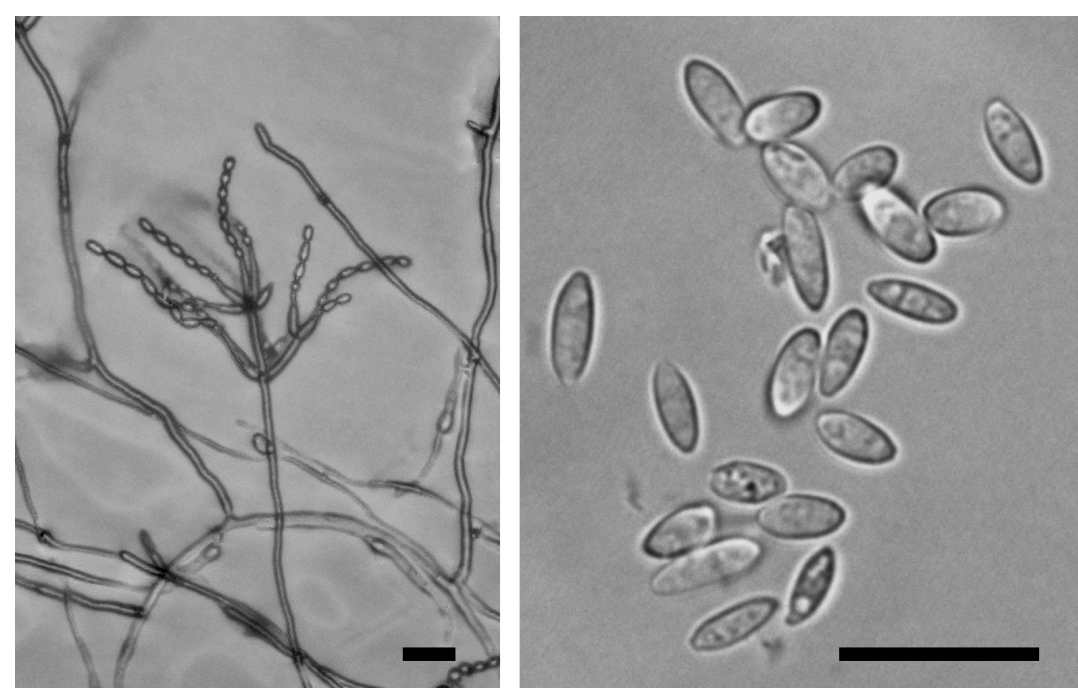

Fig. 2. Conidiogenous structures (left) and conidia (right) of Isaria javanica on SDAY (Bar $=10 \mu \mathrm{m})$. 


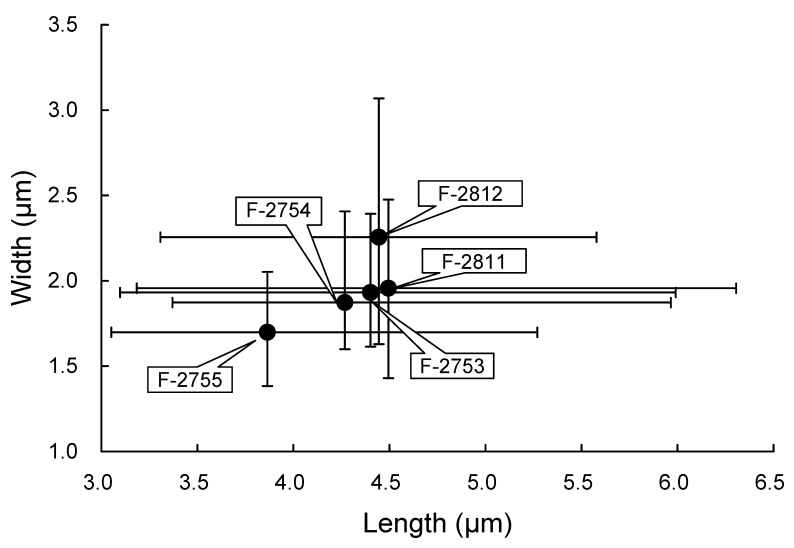

Fig. 3. Conidial dimensions of isolates of Isaria javanica on host insect cadavers ( $\bullet$ : mean; bars: range).

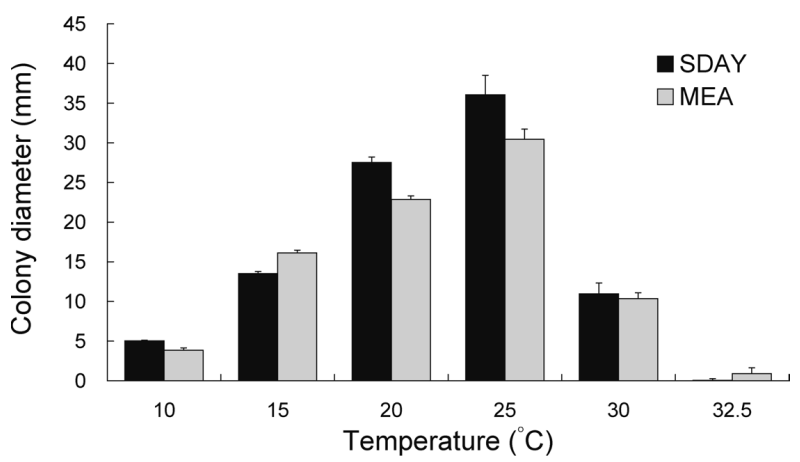

Fig. 4. Growth of Isaria javanica after $14 \mathrm{~d}$ culture on SDAY and MEA at various temperatures.

\section{Mycelial growth rate}

Among the temperatures tested, F-2754 showed growth at 10 to $30^{\circ} \mathrm{C}$. At $32.5^{\circ} \mathrm{C}$, no visible colonies developed on SDAY, whereas visible colonies were seen on three of the four MEA plates at the same temperature (Fig. 4). At $30^{\circ} \mathrm{C}$, every fungal colony became ruffled and deformed on SDAY, but was normal on MEA. Growth of the fungus was best at $25^{\circ} \mathrm{C}$, followed by at $20^{\circ} \mathrm{C}$, on both media.

\section{Molecular analysis}

All isolates used in the present study had identical sequences for the two regions analyzed (308 bp of $\beta$-tubulin and $571 \mathrm{bp}$ of ITS rDNA). The sequences were deposited with GenBank (Accession numbers of $\beta$-tubulin gene: F-2753, AB539082; F2754, AB539083; F-2755, AB539084; F-2811, AB539085; F-2812, AB539086. Those of ITS rDNA: F-2753, AB539087; F-2754, AB539088; F2755, AB539089; F-2811, AB539090; F-2812,

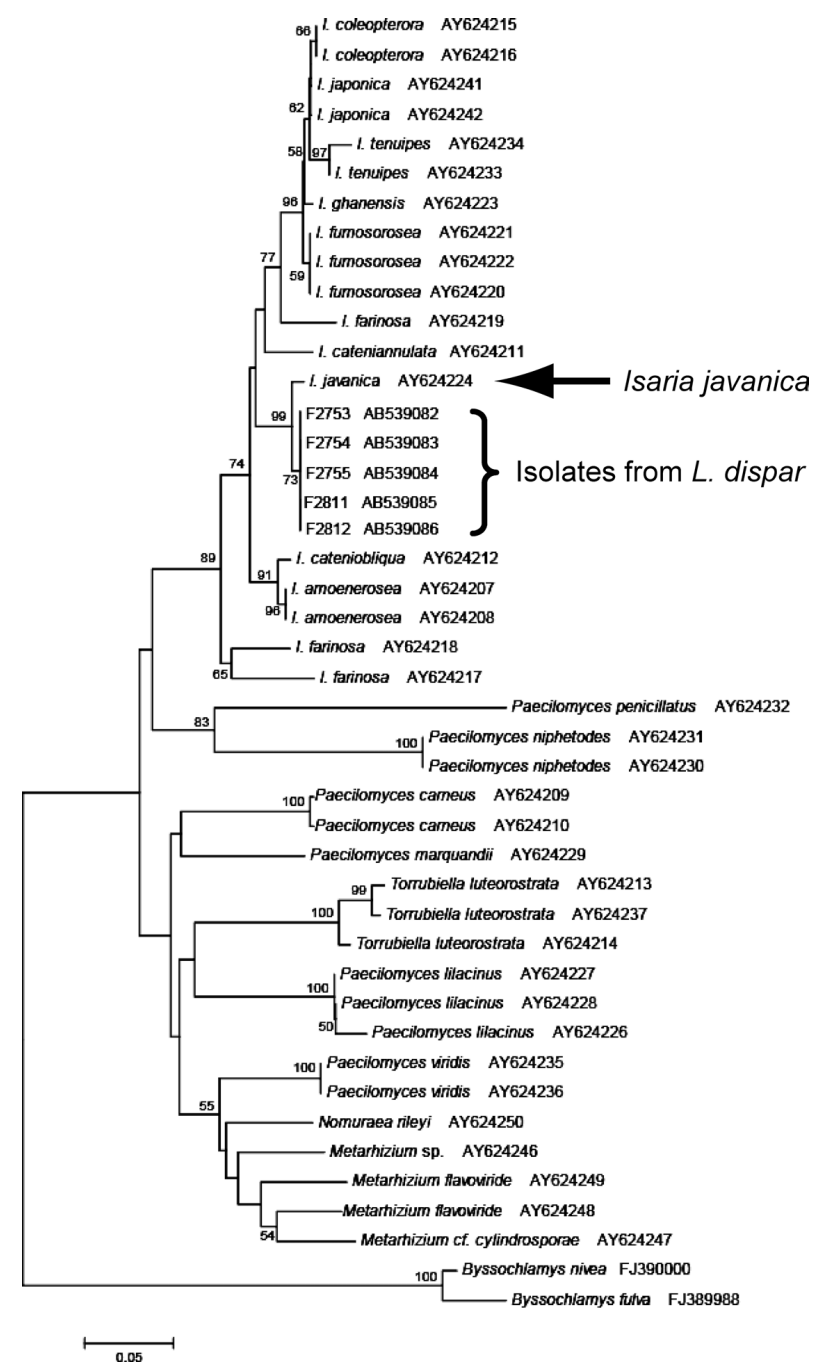

Fig. 5. Neighbor-joining tree based on analysis of the partial $\beta$-tubulin gene sequences of the isolates F-2753, F-2754, F-2755, F-2811 and F-2812 and some related species. Branch termini are labeled according to isolate numbers or species and GenBank accession numbers. Numbers above (or below) the nodes indicate bootstrap values $(\geq 50 \%)$ generated after 1,000 replications.

AB539091). A BLAST search indicated that the $\beta$ tubulin sequence of the present study had a maximal identity of $98 \%$ relative to that of $I$. javanica and the second most significant alignment to the sequences of I. fumosorosea. Similarly, the ITS rDNA of the present study was shown by a BLAST search to have a significant identity of $97-99 \%$ to Isaria species of I. javanica, I. fumosorosea, I. cateniobliqua and I. amoenerosea. In the $\beta$-tubulin phylogram, isolates of the present study grouped with I. javanica CBS 134.22 strain, which was well supported by a bootstrap value of $99 \%$ (Fig. 5). An 


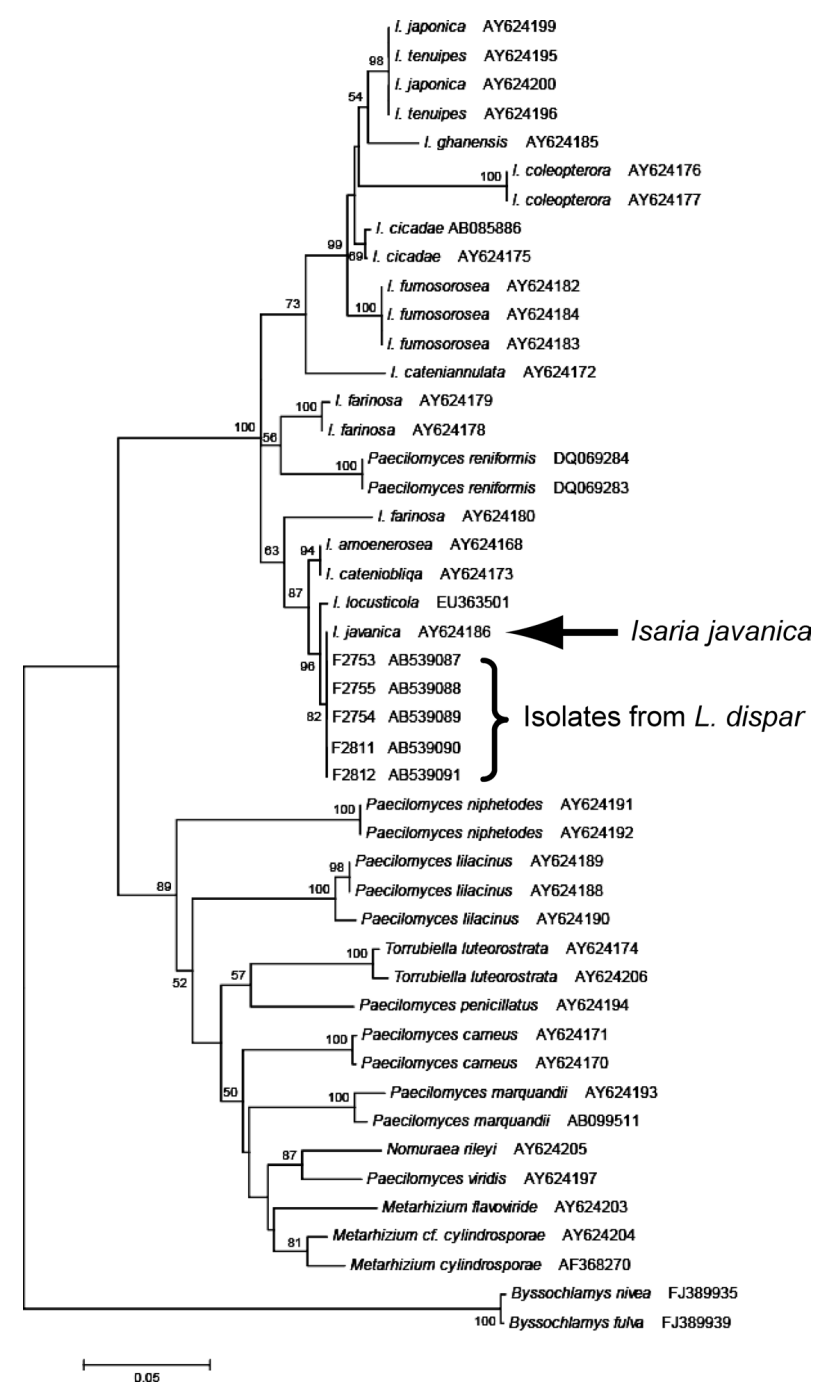

Fig. 6. Neighbor-joining tree based on analysis of the ITS1-5.8S-ITS2 rDNA sequences of the isolates F-2753, F2754, F-2755, F-2811 and F-2812 and some related species. Branch termini are labeled according to isolate numbers or species, and GenBank accession numbers. Numbers above (or below) the nodes indicate bootstrap values $(\geq 50 \%)$ generated after 1,000 replications.

ITS rDNA phylogram positioned the isolates in a significantly supported clade that included I. javanica CBS 134.22 strain (Fig. 6).

\section{Pathogenicity to Lymantria dispar larvae}

A considerable number of larvae inoculated with I. javanica did not show typical muscardine, but their bodies were soft and did not show mycelia on their body surfaces after death. There was some mortality in larvae of the control plot, and the mortalities of the inoculated plots did not correspond to the inoculum sizes. Therefore, probit analysis
Table 1. Mortalities of Lymantria dispar larvae inoculated with conidial suspension of Isaria javanica F-2754 within a period of $25 \mathrm{~d}$

\begin{tabular}{lcccrr}
\hline $\begin{array}{c}\text { Larval } \\
\text { instar }\end{array}$ & $\begin{array}{c}\text { Conidial } \\
\text { density } \\
(/ \mathrm{ml})\end{array}$ & $\begin{array}{c}\text { Number } \\
\text { of } \\
\text { insects }\end{array}$ & $\begin{array}{c}\text { Number Mortality } \\
\text { killed }\end{array}$ & $\begin{array}{c}\text { Corrected } \\
\text { mortality } \\
(\%)^{\mathrm{a}}\end{array}$ \\
\hline 3rd & 0 & 10 & 4 & 40.0 & 0.0 \\
& $10^{4}$ & 11 & 3 & 27.3 & -21.2 \\
& $10^{5}$ & 11 & 3 & 27.3 & -21.2 \\
& $10^{6}$ & 11 & 0 & 0.0 & -66.7 \\
& $10^{7}$ & 11 & 4 & 36.4 & -6.1 \\
& $10^{8}$ & 12 & 9 & 75.0 & 58.3 \\
\hline \multirow{2}{*}{ 4th (rep1) } & 0 & 10 & 3 & 30.0 & 0.0 \\
& $10^{6}$ & 10 & 2 & 20.0 & -14.3 \\
& $10^{7}$ & 11 & 6 & 54.5 & 35.1 \\
& $10^{8}$ & 11 & 10 & 90.9 & 87.0 \\
& 0 & 10 & 2 & 20.0 & 0.0 \\
\hline \multirow{2}{*}{ 4th (rep2) } & 0 & & & & \\
& $10^{4}$ & 10 & 0 & 0.0 & -25.0 \\
& $10^{5}$ & 10 & 1 & 10.0 & -12.5 \\
& $10^{6}$ & 10 & 1 & 10.0 & -12.5 \\
& $10^{7}$ & 10 & 4 & 40.0 & 25.0 \\
& $10^{8}$ & 10 & 10 & 100.0 & 100.0 \\
\hline & & & & & \\
\hline
\end{tabular}

${ }^{a}$ Corrected with Abbott's formula (Abbott, 1925).

could not be performed. Nevertheless, maximum mortality was obtained by inoculation with $1 \times 10^{8}$ conidia/ml and the mortality was $58.3-100 \%$ after correction by Abbott's method (Abbott, 1925). Mortalities by inoculating $1 \times 10^{7}$ conidia/ml were $25-35 \%$ for 4 th-instar larvae. However, mortality of the 3rd-instar larvae inoculated with $1 \times 10^{7}$ conidia/ml was less than that in the control plot (Table 1).

\section{DISCUSSION}

The verticillated arrangement of phialides, flask shape of phialides with a long slender neck, and basipetal chained conidia are features of Paecilomyces. Moreover, the pathogenicity to insects, white color of a colony, and absence of the ascigerous stage indicate that this fungus belongs to the former Section Isarioidea in genus Paecilomyces. According to the key by Samson (1974), the morphology of Paecilomyces javanicus resembles that of this fungus. Recently, P. javanicus was moved to genus Isaria, and renamed as Isaria javanica (Luangsa-ard et al., 2005). The published features and dimensions of I. javanica (=P. javanicus) are com- 
Table 2. Published features and dimensions of Isaria javanica

\begin{tabular}{|c|c|c|c|c|c|}
\hline & $\begin{array}{l}\text { Brown and Smith } \\
\text { (1957) }\end{array}$ & $\begin{array}{l}\text { Samson } \\
(1974)\end{array}$ & $\begin{array}{l}\text { Tzean } \\
(1997)\end{array}$ & $\begin{array}{c}\text { Aoki (1974) } \\
\text { Paecilomyce canadensis }\end{array}$ & $\begin{array}{c}\text { Shimazu and Takatsuka } \\
\text { (present study) }\end{array}$ \\
\hline Phialide & $6-15 \times 1.2-2 \mu \mathrm{m}$ & $8-14 \times 2-2.8 \mu \mathrm{m}$ & $5.2-11.1 \times 2.0-2.8 \mu \mathrm{m}$ & $9.0-18.0 \times 2.2-3.5 \mu \mathrm{m}$ & $\begin{array}{l}5.1-10.9 \times 1.8-2.8 \mu \mathrm{m} \\
\quad(\text { on host }) \\
4.6-13.5 \times 1.8-2.6 \mu \mathrm{m} \\
\quad(\text { on medium) }\end{array}$ \\
\hline Conidia & $\begin{array}{l}\text { cylindrical to } \\
\text { fusiform } \\
4-6 \times 1-1.5 \mu \mathrm{m}\end{array}$ & $\begin{array}{c}\text { cylindrical to } \\
\text { fusiform } \\
5-7.4 \times 1.4-1.7 \mu \mathrm{m}\end{array}$ & $\begin{array}{c}\text { ellipsoidal to } \\
\text { cylindrical } \\
3.2-5.6 \times 1.6-2.8 \mu \mathrm{m}\end{array}$ & $\begin{array}{c}\text { oblong } \\
4.0-7.5 \times 2.4-5.2 \mu \mathrm{m}\end{array}$ & $\begin{array}{l}\text { fusiform to oval } \\
3.0-6.3 \times 1.4-3.2 \mu \mathrm{m}\end{array}$ \\
\hline
\end{tabular}

pared in Table 2. Most morphological features and colony appearances of our isolates are consistent with those published. The conidial width of our fungus agreed with that of Tzean et al. (1997), but was somewhat broader than the descriptions of Brown and Smith (1957) and Samson (1974). The growth of the colony diameter corresponded with that of Samson (1974). Our fungus did not produce distinct synnema, although Samson (1974) described that $P$. javanicus occasionally produces a few synnemata of about $2 \mathrm{~cm}$ in height. DNA sequences for two genomic regions of the isolates had maximal identity to the sequences of I. javanica. Furthermore, phylogenetic analyses demonstrated that the isolates grouped together with I. javanica strongly supporting the idea that the isolates are closely related to or might be the same species as $I$. javanica. Therefore, we identified this gypsy moth pathogen as Isaria javanica.

I. javanica is morphologically similar to Paecilomyces canadensis, which has chained oblong conidia of $4-5.4 \times 2.8-3 \mu \mathrm{m}$. P. canadensis was originally described by Vuillemin (1925) as Spicaria canadensis. Brown and Smith (1957) did not observe this species themselves but combined $S$. canadensis into the genus Paecilomyces, and published on the species with the original Latin description of Vuillemin (1925). Brown and Smith (1957) regarded $P$. canadensis to be probably related to $P$. farinosus, but differed from the latter in having larger conidia. However, Vuillemin (1925) stated that $S$. canadensis was close to $S$. aphodii (=P. fumosoroseus), but is distinguished by its pink cultures and much smaller conidia. Moreover, Brown and Smith (1957) treated Paecilomyces species of cossus, canadensis and heliothis to be related species and placed them as the 'P. farinosus series'. Later, Samson (1974) published a monograph of the genus Paecilomyces, but did not mention the ' $P$. farinosus series', and treated $P$. cossus as a synonym of $P$. fumosoroseus and $P$. heliothis as a synonym of $P$. tenuipes. No description of $P$. canadensis or $S$. canadensis was made in his monograph.

The genus Paecilomyces, united by Brown and Smith (1957), has been thought by some researchers to include species distantly related each other. For example, Samson (1974) placed entomogenous species of Paecilomyces that had previously belonged to genus Isaria into section Isarioidea. Recently, Luangsa-ard et al. (2005) revised species of Paecilomyces sect. Isarioidea, by means of the $\beta$-tubulin gene and ITS rDNA, and revealed that sect. Isarioidea also is polyphyletic. However, they also discovered that many species in sect. $I S-$ arioidea formed a single clade, and restored genus Isaria and combined the species of that clade to ISaria. Consequently, they placed the former Paecilomyces species $P$. amoeneroseus, $P$. cateniannulatus, $P$. cateniobliquus, $P$. cicadae, $P$. coleopterorus, $P$. farinosus, $P$. fumosoroseus, $P$. ghanensis, $P$. javanicus and $P$. tenuipes into genus Isaria. Some other species in sect. Isarioidea remained to be further studied for their placement. However, they did not mention about the treatment of the 'P. farinosus series' and did not describe $P$. canadensis, $P$. cossus and $P$. heliothis, which are members of the ' $P$. farinosus series'. This could be because those species were not included in sect. ISarioidea by Samson (1974). Since then, studies on $P$. canadensis have been mostly limited to food, particularly for its role in the degradation of instant coffee, and no report on it as an insect pathogen has been published. Therefore, $P$. canadensis has 
not been treated as an insect pathogen in recent times, and it is generally thought to rarely cause disease in insects.

According to the key in Brown and Smith (1957), the 'P. farinosus series' differs from $P$. javanicus by having colonies persistently white or becoming yellowish in age, while colonies of the latter become pale bluish gray and conidia fusiform, which means the main difference in these species is the color of the colonies. However, cultures were not available for the study by Brown and Smith (1957), and their description was based on that of Vuillemin (1925). Therefore, there has been no study on a direct comparison of $P$. canadensis and P. javanicus. According to Aoki (1974), his isolate of $P$. canadensis formed white floccose cushions and produced numerous, aculeate, pale bright yellow, isarioid structures that were more than $2 \mathrm{~cm}$ in length and $1 \mathrm{~mm}$ in thickness. On the other hand, our isolates of I. javanica do not form synnema. Although Samson (1974) recognized that $P$. javanicus occasionally produce synnemata, Brown and Smith (1957) and Tzean et al. (1997) did not mention whether $P$. javanicus is synnematous or not. Therefore, it appears quite normal that I. javanica does not form synnemata. Vuillemin (1925) did not mention about the formation of isarioid structures of Spicaria canadensis. Consequently, the resemblance between Vuillemin's fungus and Aoki's (1974) fungus is not clear.

Samson (1974) observed a living culture of P. javanicus from Stephanoderis hampei (=Hypothenemus hampei, Coleoptera: Scolytidae) and Brachartona species (Lepidoptera: Zygaenidae), and cited Sawada (1959) as reporting Ocinara varians (Lepidoptera: Bombycidae), Archips ingentara (Lepidoptera: Tortricidae), Euproctis staudingeri (Lepidoptera: Lymantriidae) as host insects of $P$. javanicus. Samson (1974) moreover listed several specimens of $P$. javanicus, however those were on anonymous Lepidopteran pupae. Other reported host insects of this fungus are Lymantria xylina (Lepidoptera: Lymantriidae; Chen et al., 2007) and Spodoptera litura (Lepidoptera: Noctuidae; $\mathrm{Hu}$ et al., 2007). As such, most reported host insects are lepidopterans, but Scorsetti et al. (2008) reported the greenhouse whitefly Trialeurodes vaporariorum (Westwood) as a host of I. javanica. Lymantria dispar has not been reported as a host, although some species of Lymantriidae are known as a host insect.

The gypsy moth, L. dispar is a well-studied forest defoliator that is distributed widely in the northern hemisphere. Studies on the naturally occurring pathogens of this insect were compiled by Podgwaite (1981), but only two anamorphic fungi (Beauveria bassiana and Paecilomyces farinosus) are listed among the many pathogens, and there are no descriptions of $I$. javanica. Aoki (1974) reported $P$. canadensis from $L$. dispar larvae in Iwate, Japan, the same Prefecture as the present study. He found a mixed infection of $P$. canadensis with Entomophthora aulicae (=Entomophaga maimaiga). In his report, the fungus resembled $P$. farinosus except for the sizes of the conidia and the phialides. Conidia of his fungus were 4.0-7.5 $($ mean $\pm S D ; 5.3 \pm 0.7) \times 2.4-5.2 \quad(2.8 \pm 0.54) \mu \mathrm{m}$, and the fungus was identified as $P$. canadensis. In Aoki's (1974) discussion, it seemed that he did not take account of $P$. javanicus, and did not compare his fungus with $P$. javanicus. From the above points, it cannot be said whether the fungus described by Aoki (1974) is the same as the $P$. canadensis that is known to cause food degradation.

Our inoculation experiments revealed the pathogenicity of I. javanica to L. dispar larvae. However, even though the larvae were dipped into a conidial suspension of $10^{7} / \mathrm{ml}$, their mortality was less than $50 \%$, and $10^{8} / \mathrm{ml}$ was necessary to obtain high mortality. This indicates that its virulence is not so strong. The fungus occurred naturally in field, but its infection rates were small. Moreover, the fungus was found on gypsy moth larvae where E. maimaiga was prevailing and always found as mixed infections with this species. This situation of mixed infection was the same as that of $P$. canadensis observed by Aoki (1974). This author considered that the role of $P$. canadensis in regulating the gypsy moth population was obscure and, therefore, did not clarify which fungus was dominant. In our observations at the Iwate sites, all larvae infected with $I$. javanica were also infected with E. maimaiga, whereas most larvae infected with E. maimaiga were not infected with I. javanica. Consequently, E. maimaiga on the gypsy moth populations at the Iwate sites was dominant, and the role of this fungus as a natural enemy might not be substantial. However, the discovery of a new natural enemy of the gypsy moth, an important for- 
est defoliator, is significant not only to science but also in its application, and the role of this fungus should be further studied.

\section{ACKNOWLEDGMENTS}

The authors thank Dr. Bin Wang of Anhui Agricultural University for the field survey and collecting the larvae. This work was partly funded by a Grant-in-Aid for Utilizing Advanced Technologies in Agriculture, Forestry and Fisheries (2049), supported by the Ministry of Agriculture Forestry and Fisheries.

\section{REFERENCES}

Abbott, W. S. (1925) A method of computing the effectiveness of an insecticide. J. Econ. Entomol. 18: 265-267.

Aoki, J. (1974) Mixed infection of the gypsy moth, Lymantria dispar japonica Motschulsky (Lepidoptera: Lymantriidae), in a larch forest by Entomophthora aulicae (Reich.) Sorok. and Paecilomyces canadensis (Vuill.) Brown et Smith. Appl. Entomol. Zool. 9: 185-190.

Brown, A. H. and G. Smith (1957) The genus Paecilomyces Bainier and its perfect stage Byssochlamys Westing. Trans. Br. mycol. Soc. 40: 17-89.

Chen, C. C., H. G. A. Kumar, S. Kumar, S. S. Tzean and K. W. Yeh (2007) Molecular cloning, characterization, and expression of a chitinase from the entomopathogenic fungus Paecilomyces javanicus. Curr. Microbiol. 55: 8-13.

Glass, N. L. and G. C. Donaldson (1995) Development of primer sets designed for use with the PCR to amplify conserved genes from filamentous ascomycetes. Appl. Environ. Microbiol. 61: 1323-1330.

Hu, Q. B., S. X. Ren., X. C. An and M. H. Qian (2007) Insecticidal activity influence of destruxins on the patho- genicity of Paecilomyces javanicus against Spodoptera litura. J. Appl. Entomol. 131: 262-268.

Luangsa-ard, J. J., N. L. Hywel-Jones, L. Manoch and R. A. Samson (2005) On the relationships of Paecilomyces sect. Isarioidea species. Mycol. Res. 109: 581-589.

Podgwaite, J. D. (1981) Natural disease within dense gypsy moth populations. In The Gypsy Moth: Research Toward Integrated Pest Management (C. C. Doane and M. L. McManus, eds.). USDA Technical Bulletin 1584. USDA, Washington, D.C., pp. 125-134.

Samson (1974) Paecilomyces and some allied Hyphomycetes. Stud. Mycol. 6: 1-119.

Sawada, K. (1959) Descriptive catalogue of the Taiwan (Formosan) Fungi. Part XI. Spec. Bull. Coll. Agric. natn. Taiwan Univ. 8: 1-268.

Scorsetti, A. C., R. A. Humber, C. deGregorio and C. C. Lopez Lastra (2008) New records of entomopathogenic fungi infecting Bemisia tabaci and Trialeurodes vaporariorum, pests of horticultural crops, in Argentina. BioControl 53: 787-796.

Tamura, K., J. Dudley, M. Nei and S. Kumar (2007) MEGA4: Molecular Evolutionary Genetics Analysis (MEGA) software version 4.0. Mol. Biol. Evol. 24: 1596-1599.

Tzean, S. S., L. S. Hsieh and W. J. Wu (1997) Atlas of Entomopathogenic Fungi from Taiwan. National Taiwan University, Taipei. $214 \mathrm{pp}$.

Vuillemin, P. (1925) A new fungus disease of the satin moth larva. Can. Entomol. 57: 97-99.

White, T. J., T. Bruns, S. Lee and J. Taylor (1990) Amplification and direct sequencing of fungal ribosomal RNA genes for phylogenetics. In PCR Protocols: A Guide to Methods and Aplications (M. A. Innis et al., eds.). Academic Press, San Diego, pp. 315-322. 